( 2021 , The Authors. Published by Elsevier Inc. and Fass Inc. on behalf of the American Dairy Science Association ${ }^{\circledR}$. This is an open access article under the CC BY-NC-ND license (http://creativecommons.org/licenses/by-nc-nd/4.0/).

\title{
Fertility and milk production on commercial dairy farms with customized lactation lengths
}

\author{
E. E. A. Burgers, ${ }^{1,2 *} \dagger \odot$ A. Kok, ${ }^{1} \dagger \oplus$ R. M. A. Goselink, ${ }^{2} \odot$ H. Hogeveen, ${ }^{3} \oplus$ B. Kemp, ${ }^{1} \odot$ \\ and A. T. M. van Knegsel ${ }^{1}$ (D) \\ ${ }^{1}$ Adaptation Physiology Group, Wageningen University \& Research, PO Box 338, 6700 AH Wageningen, the Netherlands \\ ${ }^{2}$ Wageningen Livestock Research, Wageningen University \& Research, PO Box 338, $6700 \mathrm{AH}$ Wageningen, the Netherlands \\ ${ }^{3}$ Business Economics Group, Wageningen University \& Research, PO Box 8130, 6706 KN Wageningen, the Netherlands
}

\begin{abstract}
Drying-off, calving, and start of lactation are critical transition events for a dairy cow. As a consequence, most animal health issues occur during these periods. By extending the voluntary waiting period for first insemination after calving, calving interval (CInt) can be extended, with possible positive effects for fertility and health. Some cows might be better suited for an extended CInt than others, due to differences in milk yield level, lactation persistency, or health status, which would justify a customized CInt based on individual cow characteristics. This study aims to investigate 13 farms with customized CInt, with respect to calving to first service interval (CFSI), accomplished CInt, services per conception (SC), conception rate at first artificial insemination (CR1AI), peak yield, lactation persistency, 305-d yield, and effective lactation yield. In total, 4,858 complete lactations of Holstein Friesian cows between 2014 and 2019 from the 13 farms were grouped by parity $(1$ or $2+$ ) and CFSI (CFSI class; CFSI- $<$ 84; $84 \leq$ CFSI- $<140 ; 140 \leq$ CFSI- $<196$; $196 \leq$ CFSI- $4<252$, CFSI-5 $\geq 252$ d) or CInt (CInt class; CInt- $1<364 ; 364 \leq$ CInt- $2<420 ; 420 \leq$ CInt-3 $<476 ; 476 \leq$ CInt- $<532$, CInt-5 $\geq 532 \mathrm{~d}$ ). Cow inseminations, available for 11 out of 13 farms (3,597 complete lactations), were grouped by parity ( 1 and $2+)$ and CFSI class or CInt class. The fertility and milk production characteristics were analyzed with generalized and general linear mixed models. The CFSI class was not associated with SC, but extended CInt class was associated with increased SC (CInt-1-5; 1.11-3.70 $\mathrm{SC})$. More than $50 \%$ of cows in the CFSI class $<84 \mathrm{~d}$ ended up in longer than expected CInt $(>364 \mathrm{~d})$, showing that these cows were not able to conceive for the desired CInt. More than $50 \%$ of cows in CInt classes 3
\end{abstract}

Received November 22, 2019

Accepted May 25, 2020.

*Corresponding author: eline.burgers@wur.nl

$\dagger$ These authors contributed equally to this work. and higher (CInt $\geq 420 \mathrm{~d}$ ) had an earlier first insemination before successful insemination (CFSI class $1 ;<196$ d), showing that these extended CInt classes consisted of both cows with an extended waiting period for first insemination and cows that failed to conceive at earlier insemination(s). On most farms, lactation persistency was greatest in CInt class $1(<364 \mathrm{~d})$, probably related to the low peak yield in this class. When this shortest CInt class was excluded, persistency increased with extended CInt classes on most farms. Although at the majority of farms 305-d yield was greater in CInt $\geq 532$ d, effective lactation yield at most farms was greatest in CInt from 364 to $531 \mathrm{~d}$, especially for multiparous cows. Based on the results of this study, a CInt between 364 and 531 days seems most optimal for milk production, when high-yielding cows were selected.

Key words: extended calving interval, extended lactation, insemination, milk yield

\section{INTRODUCTION}

Drying-off, calving, and start of a new lactation are critical transition events for a dairy cow. Large changes in both physiology (e.g., calving, onset of milk production) and management (e.g., regrouping, start of milking) increase the risk for disease and culling (Butler, 2000; Fetrow et al., 2006; Pinedo et al., 2014). In most modern dairy systems, a cow faces these transition events every year, as a 1-yr calving interval (CInt) is usually aimed for. A 1-yr CInt is associated with a large average 305-d yield and better economic results compared with longer CInt (Strandberg and Oltenacu, 1989; Inchaisri et al., 2011; Steeneveld and Hogeveen, 2012).

It can be hypothesized that reducing the number of transition events per unit of time by extending CInt could be beneficial for fertility and health. First, insemination results could be improved because of a better metabolic status at the moment of insemination, as less inseminations are needed when insemination is delayed from 40 to $120 \mathrm{~d}$ after calving (Niozas et 
al., 2019b). Second, extending CInt could reduce the number of cows that are dried-off with a high milk yield (i.e., $>18 \mathrm{~kg} / \mathrm{d}$ ), which could improve udder health (Rajala-Schultz et al., 2005; Odensten et al., 2007) and welfare (Zobel et al., 2015). Finally, some farmers aim to reduce the amount of calvings and calves born for the reduction of labor related to transition management and calf care, as well as the reduction in surplus of calves for cow replacement (Mohd Nor et al., 2014).

Although a 1-yr calving interval is usually aimed for due to maximal 305-d milk yield, milk losses due to an extended CInt could be less severe than reported in the modeling studies (Strandberg and Oltenacu, 1989; Inchaisri et al., 2011; Steeneveld and Hogeveen, 2012). First, these modeling studies were based on retrospective data, which implies a potential bias in the results because farmers likely tried to achieve a 1-yr CInt, with extended CInt indicating the involuntary consequence of health or fertility issues (Garverick et al., 2013; Carvalho et al., 2014). Second, some studies mainly reported 305-d yields. With an extended CInt, however, cows have a longer lactation period and less dry days per year, which influences both milk production per day and per year (Kok et al., 2019). Alternatively, milk production could be expressed as the total lactation including the dry period (i.e., averaged per day of CInt), similar to the effective lactation yield measure (Kok et al., 2016). Finally, the negative effect of pregnancy on milk yield might be delayed when CInt is extended, increasing lactation persistency (Bormann et al., 2002; Roche, 2003). Very persistent lactations could reduce milk losses, or possibly increase production, with an extended CInt (Arbel et al., 2001; Inchaisri et al., 2011; Kok et al., 2019).

Studies suggest that the optimal calving interval might be different for individual cows (Bertilsson et al., 1997; Kolver et al., 2007; Lehmann et al., 2017). Heifers had no or lower milk yield losses in increased CInt compared with older cows (Rehn et al., 2000; Österman and Bertilsson, 2003; Lehmann et al., 2016). In addition, milk yield level, body condition, or health status could be valuable cow characteristics that determine the response of cows to an extended voluntary waiting period for first insemination (Kolver et al., 2007; Lehmann et al., 2017). Recently, some farmers in the Netherlands started to customize CInt by extending the voluntary waiting period for first insemination after calving (VWP) for (part of) their herds. It is still a challenge for farmers, however, to select cows that have persistent lactations and therefore are capable of maintaining milk production with an extended CInt.

This study aimed to investigate farms with customized CInt with respect to calving to first service interval (CFSI), accomplished CInt, services per conception
(SC), conception rate at first AI (CR1AI), peak yield, lactation persistency, 305-d yield, and effective lactation yield. We investigated multiannual data of 13 commercial Dutch dairy farms that managed their cows for a customized CInt, using various strategies to select individual cows for an extended VWP.

\section{MATERIALS AND METHODS}

\section{Herds}

With an advertisement in a Dutch farmers magazine in 2017, farmers were asked to join a network group concerning the practical applications and implications of extended CInt on farms. This advertisement resulted in 13 Dutch dairy farmers with Holstein Friesian cows that deliberately extend the VWP for (part of) their cows and that were willing to share their milk production data. From these 13 farmers, 11 farmers were able to share their insemination data. Herd size, milking system, and average milking frequency, as well as the individual strategies to increase VWP and the accomplished mean CInt, are presented in Table 1. Criteria to select cows for an extended VWP differed among farmers. Some farmers used a fixed extended VWP for all cows, meaning that they waited a certain number of days after calving before starting insemination. Other farmers selected individual cows for an extended VWP based on daily milk yield, meaning that they waited until milk production dropped below a certain level before starting insemination. A few farmers selected cows for an extended VWP based on their peak yield; a greater peak yield implied a longer waiting period before start of insemination.

\section{Data}

Data of the 13 farms were retrieved via the Dutch milk recording system (CRV, Arnhem, the Netherlands). Only data from complete lactations with a known CInt (defined as the period from calving date to next calving date) were used. Cow lactations were grouped by parity $(1$ or $2+$ ) and CFSI (CFSI- $1<84$; $84 \leq$ CFSI- $<140 ; 140 \leq$ CFSI- $3<196 ; 196 \leq$ CFSI$4<252$; CFSI-5 $\geq 252$ d) or CInt class (CInt- $<364$; $364 \leq$ CInt- $<420 ; 420 \leq$ CInt- $3<476 ; 476 \leq$ CInt- 4 $<532$; CInt-5 $\geq 532$ d), where each next CInt class was an extension of CInt with 8 wk. The CFSI classes were designed to match the CInt classes based on an assumed gestation length of $280 \mathrm{~d}$ and conception at first insemination. The Appendix gives an overview of the number of lactations per parity class, per CInt class, per farm (Appendix Table A1), and the mean CInt per parity class, per CInt class, per farm (Appendix Table 
Burgers et al.: CUSTOMIZED LACTATION LENGTH ON DUTCH DAIRY FARMS

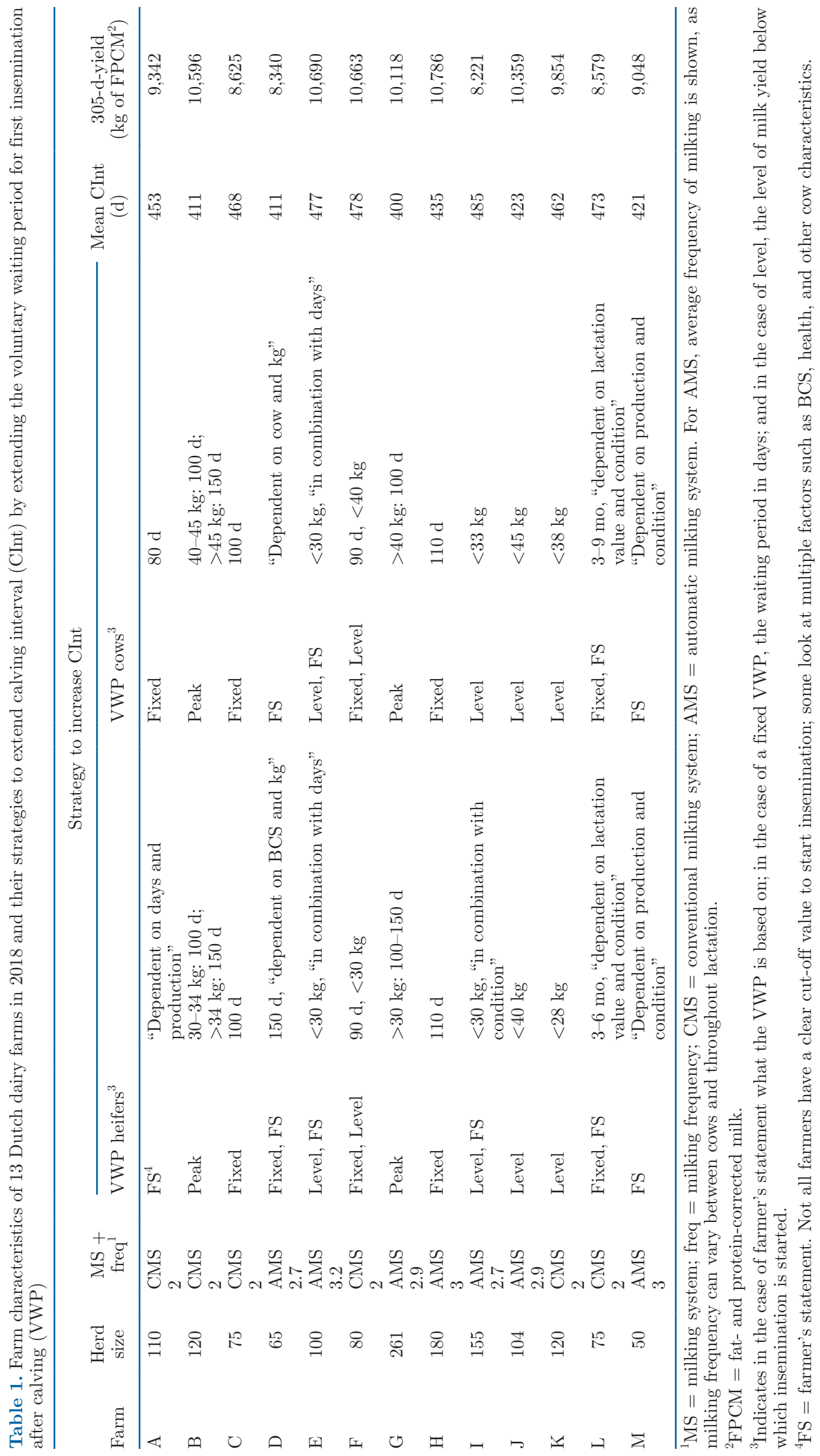


A2). The Appendix also gives an overview of the number of lactations per parity class, per CFSI class, and per farm (Appendix Table A3), and the mean CFSI per parity class, per CFSI class, and per farm (Appendix Table A4).

\section{Insemination Data}

Insemination data were available for 11 out of 13 farms, from February 2013 until March 2019. The original data set consisted of 5,487 lactations. In total, 1,890 incomplete lactations were removed. The final data set for analysis of inseminations included only complete lactations with insemination data available and consisted of 3,597 complete lactations with 6,968 inseminations. Cow inseminations were grouped by parity ( 1 or $2+)$ and CFSI or CInt class.

\section{Milk Production Data}

Milk production data were available for all 13 farms. Milk yield and composition were recorded every 4 to 6 wk, from January 2014 until January 2019. The original data set consisted of 8,447 lactations. In total, 3,589 incomplete lactations were removed. From these incomplete lactations, 1,499 lactations started after January 2018, and therefore these are likely to be ongoing at the end of the data set. The final data set for analysis of milk production consisted of 4,858 complete lactations with 43,859 milk records. Milk yield was converted to fat- and protein-corrected milk (FPCM) as milk (kg) $\times[0.337+0.116 \times$ fat content $(\%)+0.06 \times$ protein content (\%)] (CVB, 2012).

\section{Statistical Analysis}

Insemination Data. Number of SC were analyzed per CFSI classes and per CInt classes to compare between aimed CInt and result in practice. Insemination data were analyzed using 4 models. The SC was not normally distributed but followed a Poisson distribution. Number of SC per CFSI class was analyzed using a generalized linear mixed model with a Poisson distribution in SAS (PROC GLIMMIX, version 9.4, SAS Institute Inc., Cary, NC; model 1). The final model included fixed effects of parity, farm, and CFSI class. There were no interaction effects; these were removed from the model by backward selection.

The CR1AI per CFSI class was analyzed using a generalized linear mixed model with a binary distribution in SAS (PROC GLIMMIX; model 2). The final model included fixed effects of parity, farm, and CFSI class. This procedure modeled the probability that there was conception after first insemination.
The number of SC per CInt class was analyzed using a generalized linear mixed model with a Poisson distribution in SAS (PROC GLIMMIX; model 3). The final model included fixed effects of parity, farm, and CInt class. The interaction of CInt class $\times$ farm was retained in the model by backward selection of interaction effects.

The CR1AI per CInt class was analyzed using a generalized linear mixed model with a binary distribution in SAS (PROC GLIMMIX; model 4). The final model included fixed effects of parity, farm, and CInt class. All $P$-values of the least squares means were adjusted with a Bonferroni adjustment.

Milk Production Data. Milk production results were analyzed per CFSI class and per CInt class, with a mixed model in SAS (PROC MIXED), using 4 models. Two models allowed fixed effects of CFSI class or CInt class, parity, and lactation curve parameters (models 5 and 6). Significant interactions $(P<0.05)$ between the fixed effects and the lactation curve parameters were retained in the final model by backward selection. In these models, cow lactation was added as a random effect nested within farm.

Next, farm was added as a fixed effect to both the CFSI class model and the CInt class model (models 7 and 8). The results for the CFSI class model per farm can be found in Supplemental Tables S1-S4 (https:/ /doi.org/10.3168/jds.2019-17947). Significant interactions $(P<0.05)$ between the fixed effects and the lactation curve parameters were retained in the final model by backward selection. In addition to the fixed effects, the model included a random effect for repeated measures per cow lactation, assuming an unstructured covariance-structure. Based on these models, lactation curves were fitted using a Wilmink curve extended with a linear negative effect of gestation on milk production, starting at a fixed delay after conception (Wilmink, 1987; Strandberg and Lundberg, 1991):

$$
y_{t}=a+b_{t}+c^{(-k \times t)}+b_{\text {gest }} \times \max \left[\left(D_{\text {gest }}-D_{\text {delay }}\right), 0\right]
$$

where $a, b_{t}, c$, and $k$ (assumed at 0.05 ) represent the shape of the Wilmink lactation curve (Wilmink, 1987) and $b_{\text {gest }}$ represents the linear negative effect of days in gestation $\left(D_{\text {gest }}\right)$ from a fixed delay $\left(D_{\text {delay }}\right)$ after conception (Strandberg and Lundberg, 1991). The $D_{\text {delay }}$ was determined for the entire data set; the best fit, based on the Bayesian information criterion, was found for a gestation effect starting at $161 \mathrm{~d}$ after conception. From the lactation curves, we derived peak yield, lactation persistency, 305-d yield, and effective lactation yield. Lactation persistency was defined as the slope of the lactation curve from d 100 until d 212 in lactation in kilograms per day. The 305-d yield was 
Burgers et al.: CUSTOMIZED LACTATION LENGTH ON DUTCH DAIRY FARMS

Table 2. Percentage of cows per calving to first service interval (CFSI) class per calving interval (CInt) class (total lactations $=3,597$ )

\begin{tabular}{|c|c|c|c|c|c|}
\hline $\begin{array}{l}\text { CInt class }{ }^{1} \\
\text { (n of lactations) }\end{array}$ & \multicolumn{5}{|c|}{ CFSI $\operatorname{class}^{2}$ (n of lactations) } \\
\hline CInt-1 (509) & $49.8^{3}$ & 2.4 & - & - & - \\
\hline CInt-3 (813) & 12.3 & 20.3 & 59.4 & 3.3 & - \\
\hline CInt-4 (471) & 5.5 & 9.0 & 20.4 & 67.8 & 2.8 \\
\hline CInt-5 (445) & 4.2 & 6.8 & 15.6 & 28.9 & 97.2 \\
\hline
\end{tabular}

${ }^{1}$ CInt class: CInt- $1<364 \mathrm{~d} ; 364 \mathrm{~d} \leq$ CInt- $2<420 \mathrm{~d} ; 420 \mathrm{~d} \leq$ CInt-3 $<476 \mathrm{~d} ; 476 \mathrm{~d} \leq$ CInt- $4<532 \mathrm{~d}$, CInt-5 $\geq 532 \mathrm{~d}$.

${ }^{2}$ CFSI class: CFSI- $1<84 \mathrm{~d} ; 84 \mathrm{~d} \leq$ CFSI- $2<140 \mathrm{~d} ; 140 \mathrm{~d} \leq$ CFSI- $3<196 \mathrm{~d} ; 196 \mathrm{~d} \leq$ CFSI- $4<252 \mathrm{~d}$, CFSI- $5 \geq 252 \mathrm{~d}$.

${ }^{3}$ Values on the diagonal indicate the percentage of cows that end up in planned CInt class.

calculated as the area under the curve in the first 305 $\mathrm{d}$ of lactation. Effective lactation yield was calculated as the total milk yield from calving to next calving (including the dry period) and expressed as FPCM per day of CInt (Kok et al., 2016; Lehmann et al., 2016), using the average CInt for each CInt class $x$ parity class $\times$ farm combination, and assuming a 6 -wk dry period.

\section{RESULTS}

\section{CFSI and Clnt}

Based on their CFSI, cows had an expected CInt, when assuming conception at first insemination. Cows did not always end up in the expected CInt classes (Table 2). From the cows in the CFSI-1 class $(<84$ d), almost $50 \%$ ended up in the corresponding CInt class (i.e., CInt-1; <364 d). With extending CFSI class, this percentage increased. Per CFSI class, 50.2, 36.1, 36.0 , and $28.9 \%$ of cows (for CFSI-1, CFSI-2, CFSI-3, CFSI-4, respectively) ended up in a higher CInt class than planned for, based on first insemination. A small proportion of cows ended up in a shorter CInt than expected from first insemination due to a gestation shorter than $280 \mathrm{~d}$.
Based on their CInt, cows had an expected CFSI, when assuming conception at first insemination. Cows did not always originate in these expected CFSI classes (Table 3). More than $50 \%$ of cows in CInt classes 3 and higher (CInt $\geq 420 \mathrm{~d}$ ) had an earlier first insemination before successful insemination (CFSI $<196 \mathrm{~d}$; Table 3).

\section{Services per Conception and Conception Rate at First Al}

The number of SC ranged from 1 to 12 (Table 4). The number of SC was equal for extending CFSI classes. Parity class, farm, and CFSI class all affected CR1AI. The CR1AI was lower for CFSI class 3 compared with CFSI class 2. The number of SC increased with CInt classes (Table 5) and differed among farms. Both farm and CInt class affected CR1AI. The CR1AI decreased with extending CInt class. In CInt class 1 , there were some farms without cows that needed multiple inseminations. In CInt class 5, some farms had zero cows that conceived after 1 insemination.

\section{Lactation Curves}

Peak yield, lactation persistency, 305-d yield, and effective lactation yield were associated with parity class,

Table 3. Percentage of cows per calving interval (CInt) class per calving to first service interval (CFSI) class (total lactations $=3,597$ )

\begin{tabular}{|c|c|c|c|c|c|}
\hline \multirow{2}{*}{$\begin{array}{l}\text { CFSI class }{ }^{1} \\
\text { (n of lactations) }\end{array}$} & \multicolumn{5}{|c|}{ CInt $\operatorname{class}^{2}$ ( $\mathrm{n}$ of lactations) } \\
\hline & CInt-1 (509) & CInt-2 $(1,359)$ & CInt-3 (813) & CInt-4 (471) & CInt-5 (445) \\
\hline CFSI-1 (939) & $91.9^{3}$ & 19.5 & 14.2 & 11.0 & 8.8 \\
\hline CFSI-2 $(1,736)$ & 8.1 & 78.6 & 43.4 & 33.1 & 26.5 \\
\hline CFSI-3 (569) & - & 1.9 & 41.6 & 24.6 & 20.0 \\
\hline CFSI-4 (211) & - & - & 0.9 & 30.4 & 13.7 \\
\hline CFSI-5 (142) & - & - & — & 0.9 & 31.0 \\
\hline
\end{tabular}

${ }^{1}$ CFSI class: CFSI-1 $<84 \mathrm{~d} ; 84 \mathrm{~d} \leq$ CFSI- $2<140 \mathrm{~d} ; 140 \mathrm{~d} \leq$ CFSI- $3<196 \mathrm{~d} ; 196 \mathrm{~d} \leq$ CFSI- $4<252 \mathrm{~d}$; CFSI-5 $\geq 252 \mathrm{~d}$.

${ }^{2}$ CInt class: CInt- $1<364 \mathrm{~d} ; 364 \mathrm{~d} \leq$ CInt- $2<420 \mathrm{~d} ; 420 \mathrm{~d} \leq$ CInt-3 $<476 \mathrm{~d} ; 476 \mathrm{~d} \leq$ CInt- $4<532 \mathrm{~d}$, CInt-5 $\geq 532 \mathrm{~d}$.

${ }^{3}$ Values on the diagonal indicate the percentage of cows that originate from expected CFSI class. 
Table 4. Services per conception (SC) and conception rate at first insemination per calving to first service interval (CFSI) class

\begin{tabular}{|c|c|c|c|c|c|}
\hline \multirow[b]{2}{*}{ Item } & \multicolumn{5}{|c|}{ CFSI class (d) } \\
\hline & CFSI-1 $(<84)$ & CFSI-2 (84-139) & CFSI-3 (140-195) & CFSI-4 (196-251) & CFSI-5 $(\geq 252)$ \\
\hline $\begin{array}{l}\text { Services per conception } \\
(\text { mean } \pm \text { SE })\end{array}$ & $1.90 \pm 0.05$ & $1.82 \pm 0.04$ & $1.93 \pm 0.06$ & $1.76 \pm 0.10$ & $1.89 \pm 0.13$ \\
\hline $\begin{array}{l}\text { Range } S^{1} \\
\text { (minimum-maximum) }\end{array}$ & 1-11 & $1-12$ & 1-9 & $1-8$ & 1-8 \\
\hline
\end{tabular}

${ }_{\mathrm{a}, \mathrm{b}}$ Means within a row with different superscripts differ $(P=0.03)$.

${ }^{1}$ Range SC is presented per cow per lactation.

${ }^{2}$ Conception rate is defined as the percentage of cows pregnant at first AI.

CFSI class (Table 6), and CInt class (Table 7). For parity 1 , peak yield was highest in CFSI-4 and CInt-4. For parity 2+, peak yield was highest in CFSI-4 and CInt-5. For both parity classes, persistency was highest in CFSI-5 and CInt-5. For parity 1, 305-d yield was highest in CFSI-4 and CInt-4, as was the effective lactation yield. For parity 2+, 305-d yield was highest in CFSI-4 and CInt-5; however, effective lactation yield was highest in CFSI-2 and CInt-2.

Moreover, peak yield, persistency, 305-d yield, and effective lactation yield were associated with a farm effect and interactions with the lactation curve characteristics (Appendix Table A5).

\section{Peak Yield and Persistency per Farm}

Effects of CInt class on peak yield and lactation persistency were dependent on parity and farm. The modeled peak yield per farm ranged from 20.3 to $37.6 \mathrm{~kg} / \mathrm{d}$ of FPCM for parity 1, and from 26.8 to $51.4 \mathrm{~kg} / \mathrm{d}$ of FPCM for parity 2+ (Supplemental Table S1, https:// doi.org/10.3168/jds.2019-17947). For 9 out of 13 farms in parity 1, peak yield was lowest for CInt-1 compared with the peak yield of the other CInt classes within farms. For the other 4 farms, peak yield was lowest for CInt-2 (farm L), CInt-3 (farms C and M), and CInt-5 (farm J; Figure 1A). For parity 2+, the peak yield was lowest for CInt-1 for all farms compared with the peak yield of the other CInt classes within farms (Figure 1B).

The lactation persistency per farm ranged from 0.003 to $0.052 \mathrm{~kg}$ of FPCM reduction per day for parity 1 , and from 0.009 to $0.102 \mathrm{~kg}$ of $\mathrm{FPCM}$ reduction per day for parity $2+$ (Supplemental Table S2, https://doi .org/10.3168/jds.2019-17947). For7 out of 13 farms in parity 1, lactation persistency was greatest for CInt-5 compared with the lactation persistency of the other CInt classes within farms. For the other 6 farms, lactation persistency was greatest for CInt-1 (farms B, E, I, and $\mathrm{K}$ ), and CInt-4 (farms $\mathrm{C}$ and L; Figure 2A). For 7 out of 13 farms in parity $2+$, lactation persistency was greatest for CInt-5 compared with the lactation persistency of the other CInt classes within farms. For the other 6 farms, lactation persistency was greatest for CInt-1 (farms B, E, I, K, and L), and CInt-4 (farm C; Figure 2B).

\section{The 305-d Yield and Effective Lactation Yield per Farm}

Effect of CInt class on 305-d yield and effective lactation yield depended on parity and farm. The 305-d

Table 5. Services per conception (SC) and conception rate at first insemination per calving interval (CInt) class

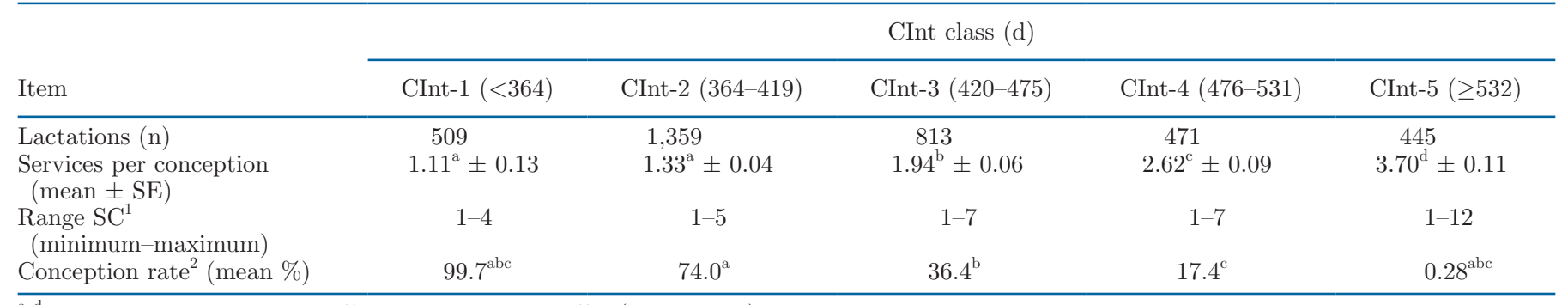

\footnotetext{
${ }^{\mathrm{a}-\mathrm{d}}$ Means within a row with different superscripts differ $(P<0.0001)$.

${ }^{1}$ Range SC is presented per cow per lactation.

${ }^{2}$ Conception rate is defined as the percentage of cows pregnant at first AI.
} 
Table 6. Peak yield, lactation persistency, 305-d yield, and effective lactation yield per calving to first service interval (CFSI) class per parity class

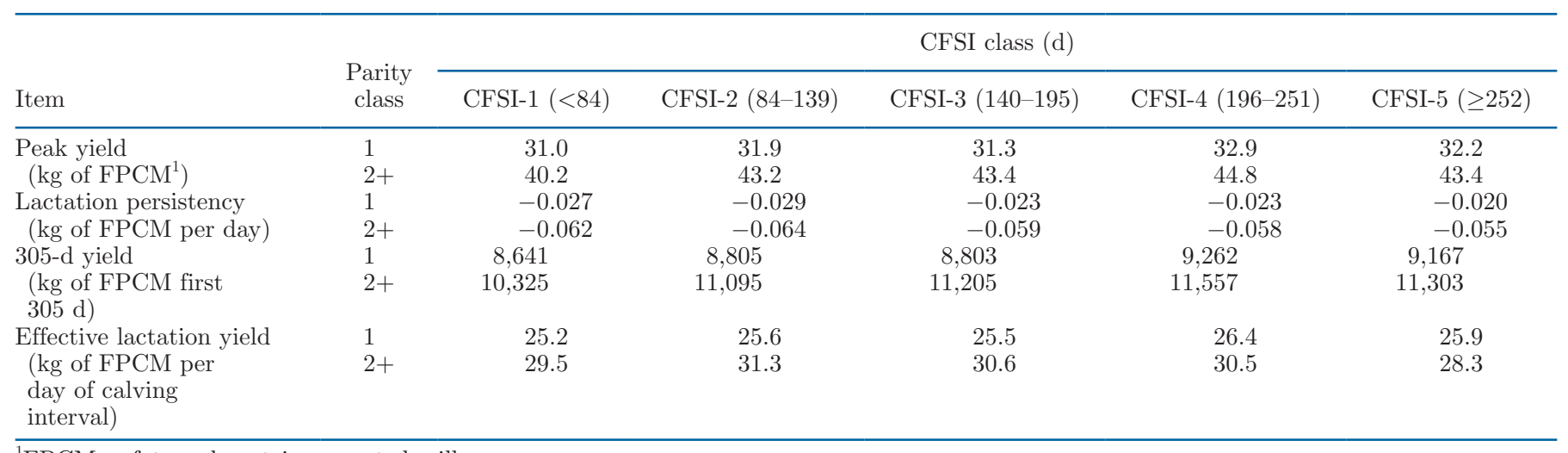

${ }^{1} \mathrm{FPCM}=$ fat- and protein-corrected milk.

yield per farm ranged from 5,822 to $10,843 \mathrm{~kg}$ of $\mathrm{FPCM}$ for parity 1 , and from 6,867 to $13,546 \mathrm{~kg}$ of $\mathrm{FPCM}$ for parity $2+$ (Supplemental Table S3, https://doi.org/10 $.3168 /$ jds.2019-17947). For parity 1, 9 out of 13 farms had greatest 305-d yield for CInt-5 compared with the other CInt classes within farms. For the other 4 farms, 305-d yield was greatest for CInt-3 (farms G and J) and CInt-4 (farms B and L; Figure 3A). For 10 out of 13 farms, 305-d yield was lowest for CInt-1, and for 3 farms 305-d yield was lowest for CInt-3 (farms C and $\mathrm{M})$ and CInt-5 (farm J). For 11 out of 13 farms in parity $2+, 305-\mathrm{d}$ yield was greatest for CInt-5 compared with the other CInt classes within farms. The other 2 farms had greatest 305-d yield for CInt-4 (farms B and J). Except for farm M, all farms had lowest 305-d yield for CInt-1 (Figure 3B).

The effective lactation yield per farm ranged from 16.7 to $32.6 \mathrm{~kg}$ of FPCM per day for parity 1, and from 19.8 to $35.5 \mathrm{~kg}$ of FPCM per day for parity $2+$ (Supplemental Table S4, https://doi.org/10.3168/jds .2019-17947). For parity 1, 6 out of 13 farms had greatest effective lactation yield for CInt-5 compared with the other CInt classes within farms. For the other 7 farms, effective lactation yield was greatest for CInt-2 (farm H), CInt-3 (farms G and J), and CInt-4 (farms B, E, I, and L; Figure 4A). For parity 2+, 6 out of 13 farms had greatest effective lactation yield for CInt-2 compared with the other CInt classes within farms. For the other 7 farms, effective lactation yield was greatest for CInt-3 (farms B and J), CInt-4 (farms A, I, K, and L), and CInt-5 (farm F; Figure 4B).

\section{DISCUSSION}

The current study aimed to investigate fertility and milk production on farms that customize CInt of their cows. On these farms, different cow characteristics were used to determine which cows to extend CInt. These cow characteristics could differ between farms and between years. This study adds insight to the consequences of customized lactation management in practice.

\section{Fertility}

Calving interval was extended by extending the VWP. Calving to first service interval was used as a measure

Table 7. Peak yield, lactation persistency, 305-d yield, and effective lactation yield per calving interval (CInt) class per parity class

\begin{tabular}{|c|c|c|c|c|c|c|}
\hline \multirow[b]{2}{*}{ Item } & \multirow{2}{*}{$\begin{array}{l}\text { Parity } \\
\text { class }\end{array}$} & \multicolumn{5}{|c|}{ CInt class $(\mathrm{d})$} \\
\hline & & CInt-1 $(<364)$ & CInt-2 (364-419) & CInt-3 (420-475) & CInt-4 (476-531) & CInt-5 $(\geq 532)$ \\
\hline$\left(\mathrm{kg}\right.$ of $\left.\mathrm{FPCM}^{1}\right)$ & $2+$ & 39.5 & 42.3 & 43.0 & 43.4 & 43.6 \\
\hline Lactation persistency & 1 & -0.025 & -0.029 & -0.027 & -0.025 & -0.020 \\
\hline (kg of FPCM per day) & $2+$ & -0.060 & -0.063 & -0.062 & -0.059 & -0.054 \\
\hline 305-d yield & 1 & 8,577 & 8,797 & 8,907 & 9,019 & 8,844 \\
\hline Effective lactation & 1 & 24.7 & 25.7 & 25.8 & 25.9 & 25.2 \\
\hline $\begin{array}{l}\text { yield ( } \mathrm{kg} \text { of FPCM } \\
\text { per day CInt) }\end{array}$ & $2+$ & 29.9 & 31.1 & 30.6 & 30.3 & 29.1 \\
\hline
\end{tabular}

${ }^{1} \mathrm{FPCM}=$ fat- and protein-corrected milk. 

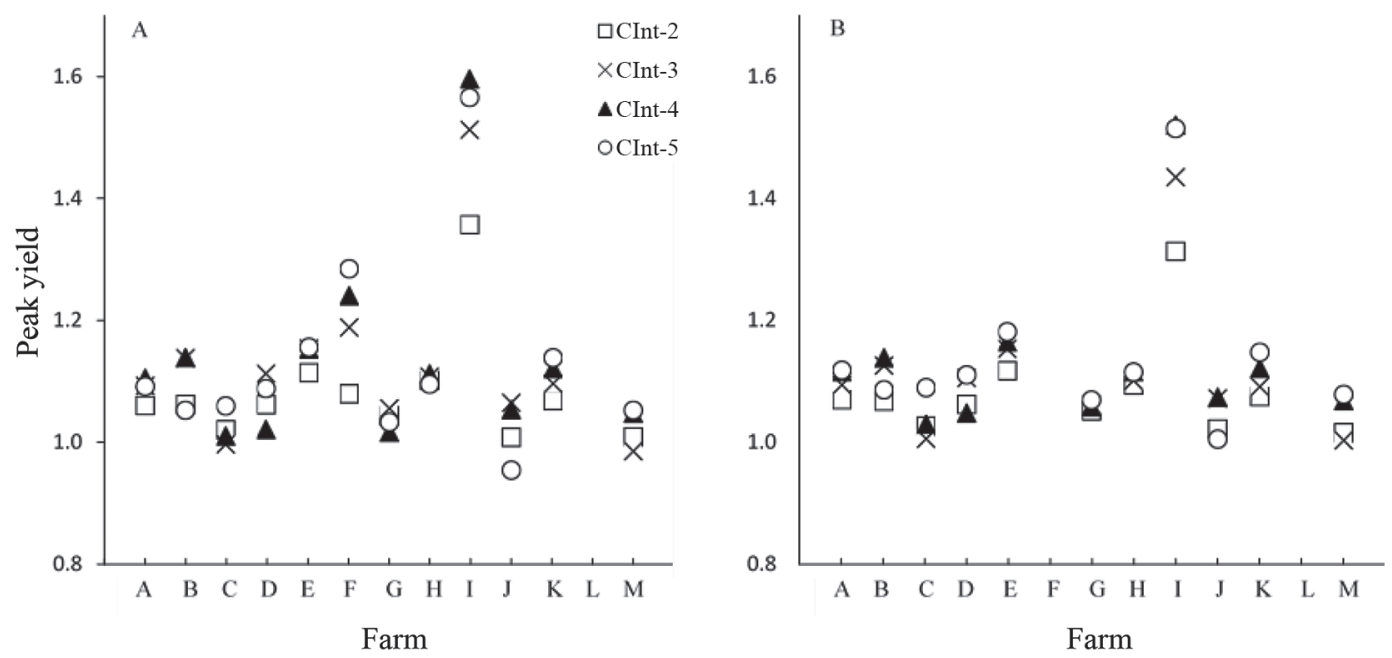

Figure 1. Peak yield per farm $(\mathrm{A}-\mathrm{M})$ per calving interval (CInt) class relative to CInt-1 (CInt-1 = 1) for cows with parity 1 (A) or parity $2+$ (B). The CInt classes are CInt-1 (<364 d), CInt-2 (364-419 d), CInt-3 (420-475 d), CInt-4 (476-531 d), and CInt-5 ( $\geq 532$ d). Farm L parity 1 could not be computed. Farm F and farm L do not have lactations with parity $2+$ in CInt-1 and are therefore not shown.

of the VWP. In the current study, CFSI class was not related to SC. The CFSI class $3(140-195 \mathrm{~d})$ had a lower CR1AI compared with CFSI class 2 (84-139 d), however there were no differences with or between the other CFSI classes. Earlier studies found a decrease in SC (Larsson and Berglund, 2000; Niozas et al., 2019b) and an improved CR1AI (Larsson and Berglund, 2000; Inchaisri et al., 2011; Niozas et al., 2019b) when VWP was extended. This was explained by the delay of insemination until a cow is possibly out of the negative energy balance (NEB). The NEB in early lactation has been associated with impaired fertility, as the lack of glucose and increased free fatty acid concentration may impair oocyte quality (Jorritsma et al., 2004; Leroy et al., 2006; Fouladi-Nashta et al., 2007). Possibly, in this study, CFSI was specifically extended for cows with high milk production as a result of farmers' strategies. Several farmers aim at insemination at a specific milk production level for all cows. This could have resulted in a similar metabolic status, and with that a similar health status at time of conception (Butler et al., 1981). A similar health status could mean similar fertility, leading to similar success of insemination (i.e., SC and conception rate at first AI; Niozas et al., 2019b). The
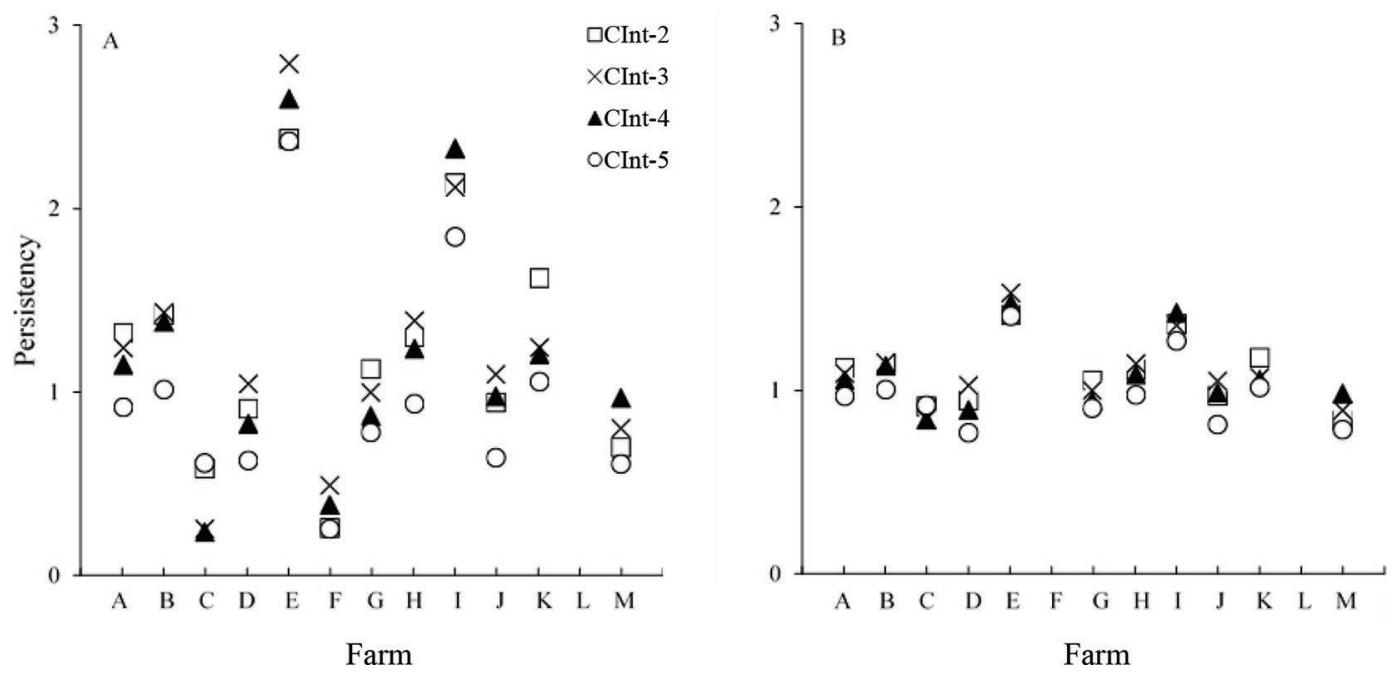

Figure 2. Persistency per farm $(\mathrm{A}-\mathrm{M})$ per calving interval (CInt) class relative to CInt-1 (CInt-1 = 1 ) for cows with parity 1 (A) or parity $2+$ (B). The CInt classes are CInt-1 (<364 d), CInt-2 (364-419 d), CInt-3 (420-475 d), CInt-4 (476-531 d), and CInt-5 ( $\geq 532$ d). Farm L parity 1 could not be computed. Farm F and farm L do not have lactations with parity $2+$ in CInt-1 and are therefore not shown. 

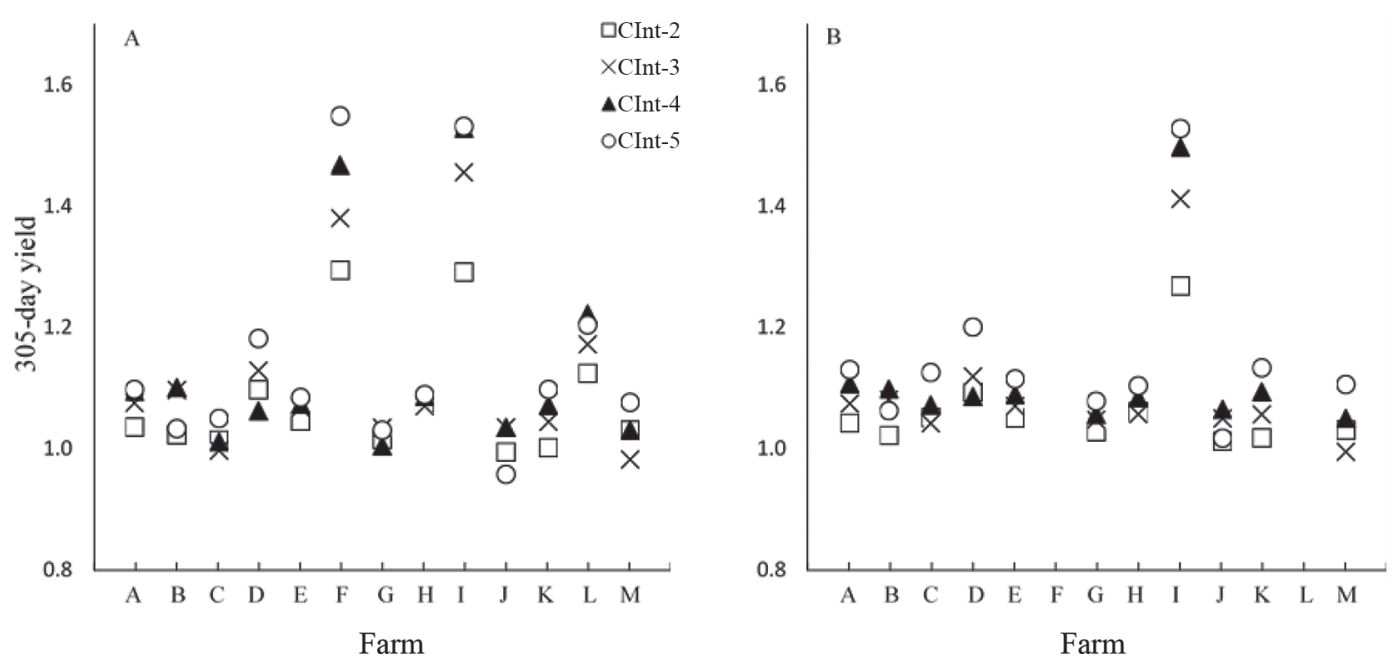

Figure 3. The 305-d yield per farm (A-M) per calving interval (CInt) class relative to CInt-1 (CInt-1 = 1) for cows with parity 1 (A) or parity 2+ (B). The CInt classes are CInt-1 (<364 d), CInt-2 (364-419 d), CInt-3 (420-475 d), CInt-4 (476-531 d), and CInt-5 ( $\geq 532$ d). Farm $\mathrm{F}$ and farm $\mathrm{L}$ do not have lactations with parity $2+$ in CInt-1 and are therefore not shown.

current study, moreover, used retrospective farm data. It is unknown whether an extended CFSI was a deliberate decision of a farmer, a real measure of the VWP, or the result of a cow not displaying estrus. Therefore, the extended CFSI classes could consist of both cows that are deliberately inseminated later and cows with estrus or health problems that could not be inseminated earlier. In extended CFSI classes, the maximum SC decreased. This finding might be related to improved fertility. With extending CFSI classes, moreover, the percentage of cows that ended up in higher CInt classes decreased, which might imply improved fertility after delayed insemination. Alternatively, cows with an ex- tended CFSI may get fewer chances to conceive before they are replaced because a lower milk yield at that time might make it undesirable to extend CInt further. The present study did not include incomplete lactations, which may have skewed SC if cows were allowed fewer inseminations in the case of an extended VWP.

The farmers in the current study aimed to customize CInt by extending VWP. An increased CFSI, however, was not always the reason for an extended CInt. In fact, around $70 \%$ of cows in a CInt $\geq 476 \mathrm{~d}$ (CInt- 4 and CInt-5) were first inseminated aiming at a shorter CInt. From CInt-3 onwards $(\geq 420$ d), the majority of cows had a lower CFSI (CFSI $<196 \mathrm{~d})$ than expected
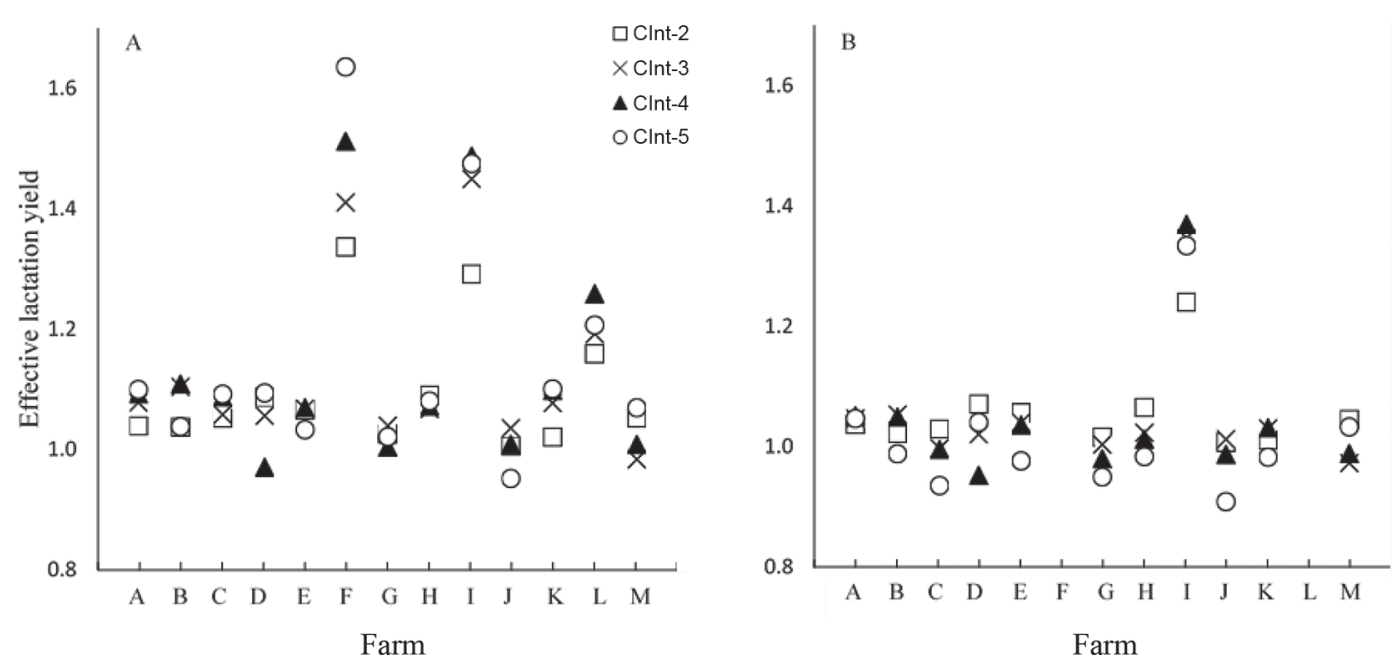

Figure 4. Effective lactation yield per farm (A-M) per calving interval (CInt) class relative to CInt-1 (CInt-1 = 1) for cows with parity 1 (A) or parity $2+$ (B). The CInt classes are CInt-1 (<364 d), CInt-2 (364-419 d), CInt-3 (420-475 d), CInt-4 (476-531 d), and CInt-5 ( $\geq 532$ d). Farm $\mathrm{F}$ and farm $\mathrm{L}$ do not have lactations with parity $2+$ in CInt-1 and are therefore not shown. 
based on CInt class. As a consequence, the extended CInt classes consisted of both cows with a delayed first insemination (either voluntarily or due to lack of estrus) and cows that were unable to conceive earlier and therefore needed multiple inseminations to become pregnant. Overall SC in this study was 1.94; SC was 1.90 for cows in parity 1 and 1.96 for cows in parity $2+$, with a maximum of 12 inseminations per cow. Farmers in this study may have been more accepting toward an extended CInt, and therefore were more inclined to inseminate a cow with difficulties to conceive multiple times, rather than replacing that cow, compared with farmers that aim for a 1-yr CInt.

Cows could end up in extended CInt due to poor fertility and therefore more days to pregnancy than aimed for based on first insemination. In fact, $50.2 \%$ of cows with CFSI $<84 \mathrm{~d}$ ended up in longer than expected CInt $(>364 \mathrm{~d})$. This showed that these cows were not able to conceive for the desired CInt, and moreover, that the longer CInt classes consisted of both cows selected for an extended CInt and cows unable to conceive sooner. A 1-yr CInt is still generally advised for an optimal economic result (Holmann et al., 1984; Steeneveld and Hogeveen, 2012), and therefore it can be assumed that the majority of Dutch dairy farmers aim for a 1-yr CInt. Less than $2 \%$ of farmers in the Netherlands, however, achieve an average CInt of $<369$ d (CRV, 2019).

\section{Lactation Curves}

In the current study, peak yield and lactation persistency were calculated according to fitted lactation curves. Earlier studies pointed out that, in terms of milk production, extending CInt seemed more successful for cows with greater lactation persistency (Arbel et al., 2001; Inchaisri et al., 2011; Kok et al., 2019), or cows with greater peak yield (Rehn et al., 2000; Lehmann et al., 2017). In the current study, the peak yield was lower for CFSI-1 class $(<84 \mathrm{~d})$ and for CInt-1 class $(<364 \mathrm{~d})$ compared with the peak yield of the other CFSI and CInt classes. Low peak yield in the short CFSI CInt classes could be related to 2 aspects. First, in the present study, it could reflect the strategy of farmers to start insemination soon when peak yield is low. Not all cows in extended CInt, however, had an extended CInt because of delayed insemination. Second, cows with a low peak yield may resume ovarian cyclicity earlier (Opsomer et al., 1998; Shrestha et al., 2004) and express estrus more easily, as milk yield has been found to negatively correlate with estrus expression (Lopez et al., 2004; Holman et al., 2011; Cutullic et al., 2012). Cows with a low peak yield, moreover, were more likely to conceive in 1 or 2 inseminations (Lean et al., 1989).

Persistency was greater in the longer CFSI classes, possibly reflecting successful selection of cows with greater persistency for extended CFSI. Farmers had different strategies to select cows for extended CFSI. Farmers that based their strategy on production level indirectly took persistency into account, as more persistent cows will take longer to drop below the cut-off level for milk yield, and are thus inseminated later and end up in greater CFSI classes. Despite that many cows in the extended CInt classes did not originate from an extended CFSI, lactation persistency increased from CInt-2 to CInt-5 (364-532 d). There are a few possible reasons for this positive relationship between CInt length and persistency. First, possibly only highproducing, persistent cows were given many chances to become pregnant, resulting in a higher proportion of persistent lactations in an extended CInt, and lowproducing or less persistent cows may have been culled and therefore did not end up in the data set. Second, it is possible that mainly high-producing cows had more difficulties to conceive and as a result involuntarily ended up in extended CInt (Chebel et al., 2004; Walsh et al., 2011). Third, increased lactation persistency in extended CInt has been related to a delayed effect of pregnancy on the lactation curve (Brotherstone et al., 2004). The persistency in the present study was calculated between d 100 and 212, a time that pregnancy was assumed to not yet affect the lactation curve (Strandberg and Lundberg, 1991; Penasa et al., 2016). However, gestation may reduce milk yield from the first month onward, which could already have reduced persistency between d 100 and 212 in lactation (Olori et al., 1997). The greater lactation persistency in the longer CInt classes could thus be related to selection of persistent animals for a long CInt or cow physiology (i.e., poor fertility of high-producing cows or a delayed pregnancy effect after later insemination; Olori et al., 1997; Brotherstone et al., 2004; Chebel et al., 2004).

On some farms, the greatest lactation persistency was found for CInt-1 ( $<364 \mathrm{~d})$. For these farms, however, the lowest peak yield was also found for CInt-1. A low peak yield is related to high persistency, whereas a high peak yield is related tolow persistency (Dekkers et al., 1998). A high peak was related to a more severe $\mathrm{NEB}$, and a more severe NEB has been related to an altered metabolic status, associated with increased plasma nonesterified fatty acid concentration and a greater incidence of metabolic diseases (Esposito et al., 2014). Both elevated levels in plasma of free fatty acids and $\beta$-hydroxybutyrate in early lactation (Chen et al., 2016) and the occurrence of mastitis after peak yield 
(Appuhamy et al., 2007) have been related to reduced lactation persistency. When peak yield was delayed and lowered as a consequence of metabolic diseases in early lactation (i.e., before peak yield), persistency was found to increase, indicating that a low peak is related to an increased persistency (Appuhamy et al., 2007; Hostens et al., 2012).

The 305-d yield reflects the lactation potential of a dairy cow (Kuhn and Hutchison, 2005; Kok et al., 2016), and is therefore expected to be correlated with effective lactation yield. For cows in parity 1, both 305$\mathrm{d}$ yield and effective lactation yield were greatest in CFSI-4 (196-251 d) and in CInt-4 (476-531 d). For cows in parity $2+$, however, greatest $305-\mathrm{d}$ yield was found in CFSI-4 (196-251 d) and in CInt-5 ( $\geq 532 \mathrm{~d}$ ), whereas greatest effective lactation yield was found in CFSI-2 (84-139) and in CInt-2 (364-419 d). Within farms, overall greatest 305-d yield was found in CInt-5 (parity 1: 9 out of 13 farms; parity 2+: 11 out of 13 farms), however, they mostly did not realize the greatest effective lactation yield in CInt-5. For cows with parity 1 , greatest effective lactation yield was found in CInt-5 in 6 farms. By selecting the best cows in terms of 305-d yield for extended CInt, it was thus possible to realize high effective lactation yield of first parity cows in extended CInt. In the other cases, effective lactation yield was still comparable to the effective lactation yield in the other CInt classes, and greater than the effective lactation yield in CInt-1. For cows with parity $2+$, greatest effective lactation yield was found in CInt5 in 1 farm. In the other farms where 305-d yield was greatest in CInt-5, effective lactation yield was often lowest in CInt-5. The effective lactation yield corrects for CInt (Kok et al., 2016). Thus, when corrected for length of CInt, the best cows in terms of 305-d yield in the CInt-5 group did not have the greatest milk production per day in extended CInt. This can be explained by a decrease in their milk production toward the end of their long lactation, and these cows would probably have accomplished greater effective lactation yield in shorter CInt (Kok et al., 2019).

The greatest 305-d yield found in CInt-5 is probably partly due to selection of cows with higher milk yield for a longer CInt by using peak yield or daily milk level to determine VWP (7 farmers). Moreover, some farmers gave their cows many chances to become pregnant (up to 12 inseminations). Depending on parity and milk yield, cows can be inseminated up to 16 mo in milk before it becomes more profitable to replace that cow (Inchaisri et al., 2012). In the current study, number of inseminations per pregnancy was much greater in the extended CInt classes compared with the shorter CInt. If only cows in CInt-5 that were planned for a shorter
CInt were considered, average number of inseminations for the CInt-5 group was 4.33. Therefore, in the current study, some of the cows in CInt-5 may have been there because these were high-producing cows that were either selected for a long CInt or were unable to conceive early and ended up in extended CInt due to multiple inseminations, contributing to the high 305-d yield in this group.

Farmers that have a fixed VWP in days for all their cows do not take individual milk yield or lactation persistency into account when assigning cows to an extended CInt. As a result, some of these farmers did not realize more persistent lactations in extended CInt. In extended CInt it is especially important to have more persistent lactations to minimize losses from extending CInt (Kok et al., 2019). Some of these farmers with a fixed VWP in days, however, argued that their goal is not to maximize milk yield per cow, but to identify and select cows capable of maintaining lactation in an extended CInt. When having the same VWP for all cows, a farmer can use cow performance in an extended VWP strategy to select cows suitable for extended CInt for the next generation.

There was a large variation in lactation curve characteristics among farms. The main reason for this was probably due to a large variation in management or possibly genetics among farms in general. When looking within farms, however, similar patterns were found among the farms for the different CInt and CFSI classes concerning milk yield and lactation curve characteristics (Figures 1-4; Supplemental Tables S1-8, https:/ /doi.org/10.3168/jds.2019-17947). Although absolute values among farms differ, cows with a higher peak, higher 305-d milk yield, and higher persistency still ended up in longer CInt classes on most farms.

\section{Motivation to Extend Clnt}

Instead of maximizing FPCM yield, farmers in the current study were interested in customizing CInt for other reasons. First, farmers aimed for potential health benefits related to an extended CInt. Extending CInt increased the time between critical transition events and could lower the number of cows that are being dried-off at high milk yields, therewith possibly improving health (Knight, 2005; Lehmann et al., 2014; Niozas et al., 2019a). Second, some farmers aimed for fewer calves born. At farm level, fewer calves result in less income from calves sold, but because calf prices are limited, it might be a benefit due to a reduction in costs (Mohd Nor et al., 2012). On a typical dairy farm, replacement rate can be assumed to be around $30 \%$ (Mohd Nor et al., 2014), indicating a surplus of 
calves that need care, labor, and feed when a 1-yr CInt is applied. A problem with selecting cows capable of extended CInt, however, is that the most suitable cows will have the longest CInt, and therefore the fewest number of calves. Farmers in the current study did take this into account when deciding on selection strategy, keeping calves from cows that were persistent in earlier lactations and inseminating less persistent cows with beef bulls (e.g., Belgian Blue) to sell the crossbred calves to the veal industry. Third, farmers aimed for a reduction in farm labor, mainly because of less transition management (i.e., drying-off, calving, start of lactation) and less calf care. Possible positive effects of extended CInt on health, fertility, and farm labor should be subject of further studies to conclude on the viability of customizing CInt on farms.

\section{CONCLUSIONS}

In this study, increased CFSI was not related to SC or conception rate at first AI on 13 commercial Dutch dairy farms that customize calving intervals by increasing the VWP for (part of) their herd. Longer CInt was related to increased $\mathrm{SC}$ and decreased conception rate at first AI. On most farms, persistency was greatest in the lowest CInt class $(<364 \mathrm{~d})$, probably related to the low peak yield in this class. Excluding this short CInt class, persistency increased with extending CInt on most farms. Though 305-d yield was greater in the longest CInt class ( $\geq 532 \mathrm{~d})$ at the majority of farms, effective lactation yield at most farms was greatest in CInt from 364 to 531 d, especially for multiparous cows. Based on the results of this study, it differs per farm what strategy in terms of waiting period for first insemination is optimal for milk production. For heifers on most farms, a CFSI of more than $196 \mathrm{~d}$ resulted in greatest effective lactation yield, when high-yielding heifers (differs per farm; > 7,500-11,000 kg of FPCM/305 d) were selected. For cows on most farms, a CFSI of more than $140 \mathrm{~d}$ resulted in greatest effective lactation yield, when high-yielding cows (differs per farm; >9,500-12,000 kg of $\mathrm{FPCM} / 305 \mathrm{~d}$ ) were selected.

\section{ACKNOWLEDGMENTS}

The authors thank the participating farmers and CRV (Arnhem, the Netherlands) for providing the data. This study was financed by DairyNL (ZuivelNL; organization of the Dutch dairy supply chain, The Hague, the Netherlands) and the Dutch Ministry of Agriculture, Nature and Food Quality (LNV, The Hague, the Netherlands) as part of the research program 'One Health for Food' (1H4F, The Hague, the Netherlands). The authors have not stated any conflicts of interest.

\section{REFERENCES}

Appuhamy, J. A. D. R. N., B. G. Cassell, C. D. Dechow, and J. B. Cole. 2007. Phenotypic relationships of common health disorders in dairy cows to lactation persistency estimated from daily milk weights. J. Dairy Sci. 90:4424-4434. https://doi.org/10.3168/jds .2007-0077.

Arbel, R., Y. Bigun, E. Ezra, H. Sturman, and D. Hojman. 2001. The effect of extended calving intervals in high lactating cows on milk production and profitability. J. Dairy Sci. 84:600-608. https://doi .org/10.3168/jds.S0022-0302(01)74513-4.

Bertilsson, J., B. Berglund, G. Ratnayake, K. Svennersten-Sjaunja, and H. Wiktorsson. 1997. Optimising lactation cycles for the highyielding dairy cow. A European perspective. Livest. Prod. Sci. 50:5-13. https://doi.org/10.1016/S0301-6226(97)00068-7.

Bormann, J., G. R. Wiggans, T. Druet, and N. Gengler. 2002. Estimating effects of permanent environment, lactation stage, age, and pregnancy on test-day yield. J. Dairy Sci. 85:263.e1-263.e21. https://doi.org/10.3168/jds.S0022-0302(02)74076-9.

Brotherstone, S., R. Thompson, and I. M. S. White. 2004. Effects of pregnancy on daily milk yield of Holstein-Friesian dairy cattle. Livest. Prod. Sci. 87:265-269. https://doi.org/10.1016/j.livprodsci 2003.07.014.

Butler, W. R., R. W. Everett, and C. E. Coppock. 1981. The relationships between energy balance, milk production and ovulation in postpartum Holstein cows. J. Anim. Sci. 53:742-748. https://doi .org $/ 10.2527 /$ jas1981.533742x.

Butler, W. R. 2000. Nutritional interactions with reproductive performance in dairy cattle. Anim. Reprod. Sci. 60-61:449-457. https:// doi.org/10.1016/S0378-4320(00)00076-2.

Carvalho, P. D., A. H. Souza, M. C. Amundson, K. S. Hackbart, M. J. Fuenzalida, M. M. Herlihy, H. Ayres, A. R. Dresch, L. M. Vieira, J. N. Guenther, R. R. Grummer, P. M. Fricke, R. D. Shaver, and M. C. Wiltbank. 2014. Relationships between fertility and postpartum changes in body condition and body weight in lactating dairy cows. J. Dairy Sci. 97:3666-3683. https://doi.org/10.3168/ jds.2013-7809.

Chebel, R. C., J. E. Santos, J. P. Reynolds, R. L. Cerri, S. O. Juchem, and M. Overton. 2004. Factors affecting conception rate after artificial insemination and pregnancy loss in lactating dairy cows. Anim. Reprod. Sci. 84:239-255. https://doi.org/10.1016/j .anireprosci.2003.12.012.

Chen, J., A. Kok, G. Remmelink, J. J. Gross, R. Bruckmaier, B. Kemp, and A. Van Knegsel. 2016. Effects of dry period length and dietary energy source on lactation curve characteristics over 2 subsequent lactations. J. Dairy Sci. 99:9287-9299. https://doi.org/ 10.3168/jds.2016-11253.

CRV. 2019. International Dutch Cattle Improvement Co-operative. Jaarstatistieken 2018. Accessed Aug. 10, 2019. https://www .crv4all.nl/downloads/crv/jaarverslag/.

Cutullic, E., L. Delaby, Y. Gallard, and C. Disenhaus. 2012. Towards a better understanding of the respective effects of milk yield and body condition dynamics on reproduction in Holstein dairy cows. Animal 6:476-487. https://doi.org/10.1017/S175173111100173X.

CVB. 2012. Cvb tabellenboek veevoeding (feedstuff table 2012), Centraal Veevoeder Bureau Lelystad, the Netherlands.

Dekkers, J. C. M., J. H. Ten Hag, and A. Weersink. 1998. Economic aspects of persistency of lactation in dairy cattle. Livest. Prod. Sci. 53:237-252. https://doi.org/10.1016/S0301-6226(97)00124-3.

Esposito, G., P. C. Irons, E. C. Webb, and A. Chapwanya. 2014. Interactions between negative energy balance, metabolic diseases, uterine health and immune response in transition dairy cows. Anim. Reprod. Sci. 144:60-71. https://doi.org/10.1016/j.anireprosci.2013 .11 .007 .

Fetrow, J., K. V. Nordlund, and H. D. Norman. 2006. Invited review: Culling: Nomenclature, definitions, and recommendations. J. Dairy Sci. 89:1896-1905. https://doi.org/10.3168/jds.S0022 -0302(06)72257-3.

Fouladi-Nashta, A. A., C. G. Gutierrez, J. G. Gong, P. C. Garnsworthy, and R. Webb. 2007. Impact of dietary fatty acids on oocyte 
quality and development in lactating dairy cows. Biol. Reprod. 77:9-17. https://doi.org/10.1095/biolreprod.106.058578.

Garverick, H. A., M. N. Harris, R. Vogel-Bluel, J. D. Sampson, J. Bader, W. R. Lamberson, J. N. Spain, M. C. Lucy, and R. S. Youngquist. 2013. Concentrations of nonesterified fatty acids and glucose in blood of periparturient dairy cows are indicative of pregnancy success at first insemination. J. Dairy Sci. 96:181-188. https://doi.org/10.3168/jds.2012-5619.

Holman, A., J. Thompson, J. Routly, J. Cameron, D. Jones, D. GroveWhite, R. Smith, and H. Dobson. 2011. Comparison of oestrus detection methods in dairy cattle. Vet. Rec. 169:47. https://doi .org/10.1136/vr.d2344.

Holmann, F. J., C. R. Shumway, R. W. Blake, R. B. Schwart, and E. M. Sudweeks. 1984. Economic value of days open for Holstein cows of alternative milk yields with varying calving intervals1. J. Dairy Sci. 67:636-643. https://doi.org/10.3168/jds.S0022-0302(84)81349 -1 .

Hostens, M., J. Ehrlich, B. Van Ranst, and G. Opsomer. 2012. Onfarm evaluation of the effect of metabolic diseases on the shape of the lactation curve in dairy cows through the milkbot lactation model. J. Dairy Sci. 95:2988-3007. https://doi.org/10.3168/ jds.2011-4791.

Inchaisri, C., A. De Vries, R. Jorritsma, and H. Hogeveen. 2012. Improved knowledge about conception rates influences the decision to stop insemination in dairy cows. Reprod. Domest. Anim. 47:820826. https://doi.org/10.1111/j.1439-0531.2011.01975.x.

Inchaisri, C., R. Jorritsma, P. L. A. M. Vos, G. C. van der Weijden, and H. Hogeveen. 2011. Analysis of the economically optimal voluntary waiting period for first insemination. J. Dairy Sci. 94:38113823. https://doi.org/10.3168/jds.2010-3790.

Jorritsma, R., M. L. César, J. T. Hermans, C. L. J. J. Kruitwagen, P. L. A. M. Vos, and T. A. M. Kruip. 2004. Effects of non-esterified fatty acids on bovine granulosa cells and developmental potential of oocytes in vitro. Anim. Reprod. Sci. 81:225-235. https://doi .org/10.1016/j.anireprosci.2003.10.005.

Knight, C. H. 2005. Extended lactation: Turning theory into reality. Adv. Dairy Technol. 17:113-123.

Kok, A., J. O. Lehmann, B. Kemp, H. Hogeveen, C. E. van Middelaar, I. J. M. de Boer, and A. T. M. van Knegsel. 2019. Production, partial cash flows and greenhouse gas emissions of simulated dairy herds with extended lactations. Animal 13:1074-1083. https://doi .org/10.1017/S1751731118002562.

Kok, A., C. E. van Middelaar, B. Engel, A. T. M. van Knegsel, H. Hogeveen, B. Kemp, and I. J. M. de Boer. 2016. Effective lactation yield: A measure to compare milk yield between cows with different dry period lengths. J. Dairy Sci. 99:2956-2966. https:// doi.org/10.3168/jds.2015-10559.

Kolver, E. S., J. Roche, C. Burke, J. Kay, and P. Aspin. 2007. Extending lactation in pasture-based dairy cows: I. Genotype and diet effect on milk and reproduction. J. Dairy Sci. 90:5518-5530. https: //doi.org/10.3168/jds.2007-0324.

Kuhn, M. T., and J. Hutchison. 2005. Methodology for estimation of days dry effects. J. Dairy Sci. 88:1499-1508. https://doi.org/10 .3168/jds.S0022-0302(05)72818-6.

Larsson, B., and B. Berglund. 2000. Reproductive performance in cows with extended calving interval. Reprod. Domest. Anim. 35:277279. https://doi.org/10.1046/j.1439-0531.2000.00278.x.

Lean, I. J., J. C. Galland, and J. L. Scott. 1989. Relationships between fertility, peak milk yields and lactational persistency in dairy cows. Theriogenology 31:1093-1103. https://doi.org/10.1016/0093 $-691 X(89) 90493-7$.

Lehmann, J. O., J. G. Fadel, L. Mogensen, T. Kristensen, C. Gaillard, and E. Kebreab. 2016. Effect of calving interval and parity on milk yield per feeding day in Danish commercial dairy herds. J. Dairy Sci. 99:621-633. https://doi.org/10.3168/jds.2015-9583.

Lehmann, J. O., L. Mogensen, and T. Kristensen. 2014. Extended lactations may improve cow health, productivity and reduce greenhouse gas emissions from organic dairy production. Org. Agric. 4:295-299. https://doi.org/10.1007/s13165-014-0070-6.
Lehmann, J. O., L. Mogensen, and T. Kristensen. 2017. Early lactation production, health, and welfare characteristics of cows selected for extended lactation. J. Dairy Sci. 100:1487-1501. https:/ /doi.org/10.3168/jds.2016-11162.

Leroy, J. L. M. R., T. Vanholder, G. Opsomer, A. Van Soom, and A. de Kruif. 2006. The in vitro development of bovine oocytes after maturation in glucose and $\beta$-hydroxybutyrate concentrations associated with negative energy balance in dairy cows. Reprod. Domest. Anim. 41:119-123. https://doi.org/10.1111/j.1439-0531 2006.00650.x.

Lopez, H., L. D. Satter, and M. C. Wiltbank. 2004. Relationship between level of milk production and estrous behavior of lactating dairy cows. Anim. Reprod. Sci. 81:209-223. https://doi.org/10 .1016/j.anireprosci.2003.10.009.

Mohd Nor, N., W. Steeneveld, and H. Hogeveen. 2014. The average culling rate of Dutch dairy herds over the years 2007 to 2010 and its association with herd reproduction, performance and health. J. Dairy Res. 81:1-8. https://doi.org/10.1017/S0022029913000460.

Mohd Nor, N., W. Steeneveld, M. C. M. Mourits, and H. Hogeveen. 2012. Estimating the costs of rearing young dairy cattle in the Netherlands using a simulation model that accounts for uncertainty related to diseases. Prev. Vet. Med. 106:214-224. https:// doi.org/10.1016/j.prevetmed.2012.03.004.

Niozas, G., G. Tsousis, C. Malesios, I. Steinhöfel, C. Boscos, H. Bollwein, and M. Kaske. 2019a. Extended lactation in high-yielding dairy cows. Ii. Effects on milk production, udder health, and body measurements. J. Dairy Sci. 102:811-823. https://doi.org/ 10.3168/jds.2018-15117.

Niozas, G., G. Tsousis, I. Steinhöfel, C. Brozos, A. Römer, S. Wiedemann, H. Bollwein, and M. Kaske. 2019b. Extended lactation in high-yielding dairy cows. I. Effects on reproductive measurements. J. Dairy Sci. 102:799-810. https://doi.org/10.3168/jds.2018-15115.

Odensten, M. O., B. Berglund, K. P. Waller, and K. Holtenius. 2007. Metabolism and udder health at dry-off in cows of different breeds and production levels. J. Dairy Sci. 90:1417-1428. https://doi.org/ 10.3168/jds.S0022-0302(07)71627-2.

Olori, V., S. Brotherstone, W. Hill, and B. McGuirk. 1997. Effect of gestation stage on milk yield and composition in Holstein Friesian dairy cattle. Livest. Prod. Sci. 52:167-176. https://doi.org/10 .1016/S0301-6226(97)00126-7.

Opsomer, G., M. Coryn, H. Deluyker, and A. de Kruif. 1998. An analysis of ovarian dysfunction in high yielding dairy cows after calving based on progesterone profiles. Reprod. Domest. Anim. 33:193-204. https://doi.org/10.1111/j.1439-0531.1998.tb01342.x.

Österman, S., and J. Bertilsson. 2003. Extended calving interval in combination with milking two or three times per day: Effects on milk production and milk composition. Livest. Prod. Sci. 82:139 149. https://doi.org/10.1016/S0301-6226(03)00036-8.

Penasa, M., M. De Marchi, and M. Cassandro. 2016. Effects of pregnancy on milk yield, composition traits, and coagulation properties of Holstein cows. J. Dairy Sci. 99:4864-4869. https://doi.org/ 10.3168/jds.2015-10168.

Pinedo, P. J., A. Daniels, J. Shumaker, and A. De Vries. 2014. Dynamics of culling for Jersey, Holstein, and Jersey $\times$ Holstein crossbred cows in large multibreed dairy herds. J. Dairy Sci. 97:2886-2895. https://doi.org/10.3168/jds.2013-7685.

Rajala-Schultz, P. J., J. S. Hogan, and K. L. Smith. 2005. Short communication: Association between milk yield at dry-off and probability of intramammary infections at calving. J. Dairy Sci. 88:577-579. https://doi.org/10.3168/jds.S0022-0302(05)72720-X.

Rehn, H., B. Berglund, U. Emanuelson, G. Tengroth, and J. Philipsson. 2000. Milk production in Swedish dairy cows managed for calving intervals of 12 and 15 months. Acta Agric. Scand. Anim. Sci. 50:263-271. https://doi.org/10.1080/090647000750069458.

Roche, J. R. 2003. Effect of pregnancy on milk production and bodyweight from identical twin study. J. Dairy Sci. 86:777-783. https:/ /doi.org/10.3168/jds.S0022-0302(03)73659-5.

Shrestha, H. K., T. Nakao, T. Higaki, T. Suzuki, and M. Akita. 2004. Resumption of postpartum ovarian cyclicity in high-producing 
Holstein cows. Theriogenology 61:637-649. https://doi.org/10 .1016/S0093-691X(03)00233-4.

Steeneveld, W., and H. Hogeveen. 2012. Economic consequences of immediate or delayed insemination of a cow in oestrus. Vet. Rec. 171:17. https://doi.org/10.1136/vr.100183.

Strandberg, E., and C. Lundberg. 1991. A note on the estimation of environmental effects on lactation curves. Anim. Prod. 53:399-402. https://doi.org/10.1017/S0003356100020420.

Strandberg, E., and P. A. Oltenacu. 1989. Economic consequences of different calving intervals. Acta Agric. Scand. Anim. Sci. 39:407420. https://doi.org/10.1080/00015128909438534.

Walsh, S. W., E. J. Williams, and A. C. O. Evans. 2011. A review of the causes of poor fertility in high milk producing dairy cows. Anim. Reprod. Sci. 123:127-138. https://doi.org/10.1016/j .anireprosci.2010.12.001.

Wilmink, J. B. M. 1987. Adjustment of test-day milk, fat and protein yield for age, season and stage of lactation. Livest. Prod. Sci. 16:335-348. https://doi.org/10.1016/0301-6226(87)90003-0.
Zobel, G., D. M. Weary, K. E. Leslie, and M. A. G. von Keyserlingk. 2015. Invited review: Cessation of lactation: Effects on animal welfare. J. Dairy Sci. 98:8263-8277. https://doi.org/10.3168/jds.2015 $-9617$.

\section{ORCIDS}

E. E. A. Burgers @ https://orcid.org/0000-0002-1586-1570

A. Kok () https://orcid.org/0000-0002-6024-5339

R. M. A. Goselink @ https://orcid.org/0000-0002-1610-0546

H. Hogeveen (1) https://orcid.org/0000-0002-9443-1412

B. Kemp (ㄴ) https://orcid.org/0000-0002-9765-9105

A. T. M. van Knegsel ๑ https://orcid.org/0000-0003-1959-3363

\section{APPENDIX}

Table A1. Number of complete lactations per farm, calving interval (CInt ${ }^{1}$ ) class, and parity class (total lactations $\left.=4,858\right)$

\begin{tabular}{|c|c|c|c|c|c|c|c|c|c|c|c|}
\hline Farm & \multicolumn{5}{|c|}{ Parity 1} & \multicolumn{5}{|c|}{ Parity $2+$} & Total \\
\hline A & 7 & 47 & 42 & 16 & 14 & 13 & 107 & 62 & 26 & 11 & 345 \\
\hline $\mathrm{C}$ & 11 & 23 & 16 & 9 & 19 & 20 & 53 & 40 & 29 & 20 & 240 \\
\hline D & 25 & 39 & 13 & 5 & 7 & 32 & 46 & 25 & 14 & 10 & 216 \\
\hline $\mathrm{E}$ & 14 & 41 & 17 & 14 & 11 & 33 & 60 & 53 & 32 & 37 & 312 \\
\hline $\mathrm{H}$ & 5 & 157 & 48 & 17 & 13 & 9 & 209 & 104 & 39 & 26 & 627 \\
\hline I & 4 & 15 & 27 & 47 & 70 & 14 & 52 & 72 & 65 & 60 & 426 \\
\hline $\mathrm{J}$ & 51 & 51 & 26 & 8 & 12 & 59 & 88 & 44 & 19 & 32 & 390 \\
\hline K & 26 & 40 & 20 & 18 & 9 & 40 & 90 & 56 & 32 & 34 & 365 \\
\hline $\mathrm{L}$ & 2 & 21 & 25 & 8 & 21 & 0 & 12 & 31 & 30 & 46 & 196 \\
\hline M & 18 & 22 & 8 & 6 & 4 & 29 & 30 & 20 & 13 & 5 & 155 \\
\hline Total & 321 & 707 & 359 & 191 & 206 & 416 & 1,166 & 755 & 403 & 334 & 4,858 \\
\hline
\end{tabular}

${ }^{1}$ CInt-1: $<364$ d, CInt-2: 364-419 d, CInt-3: 420-475 d, CInt-4: 476-531 d, CInt-5: $\geq 532$ d.

Table A2. Mean calving interval (CInt $\left.{ }^{1}\right)$ per farm, CInt class, and parity class

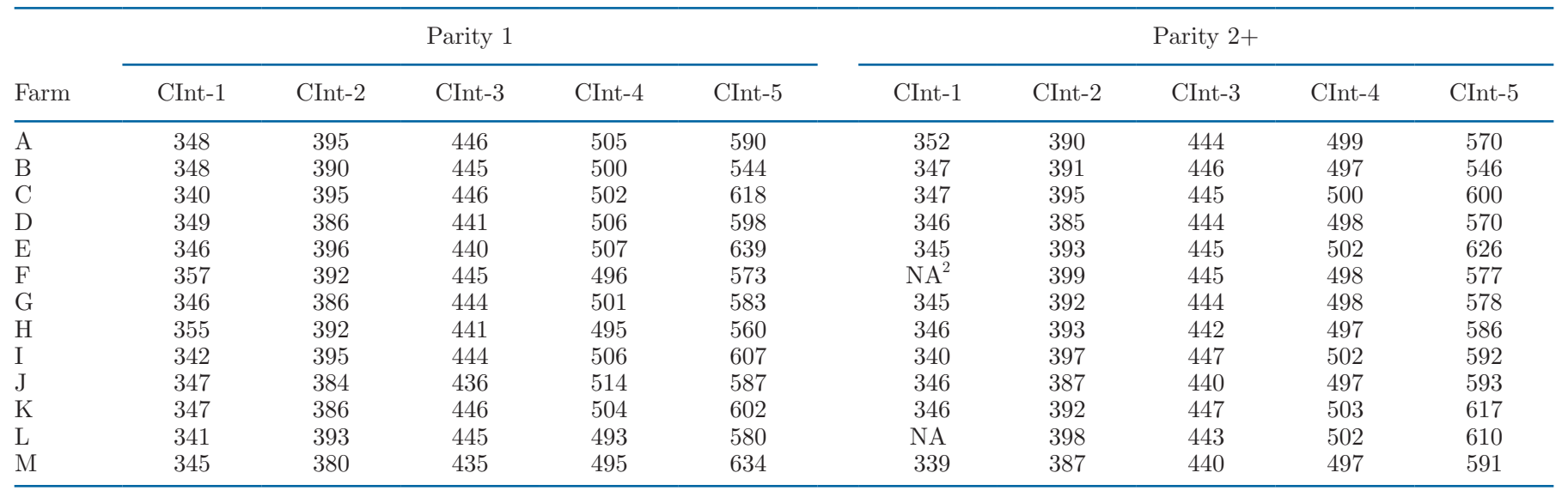

${ }^{1}$ CInt-1: <364 d, CInt-2: 364-419 d, CInt-3: 420-475 d, CInt-4: 476-531 d, CInt-5: $\geq 532$ d.

${ }^{2} \mathrm{NA}=$ not available; in this farm, parity class and CInt class were no lactations. 
Table A3. Number of complete lactations per farm, calving to first service interval $\left(\mathrm{CFSI}^{1}\right)$ class, and parity class (total lactations $\left.=3,597\right)$

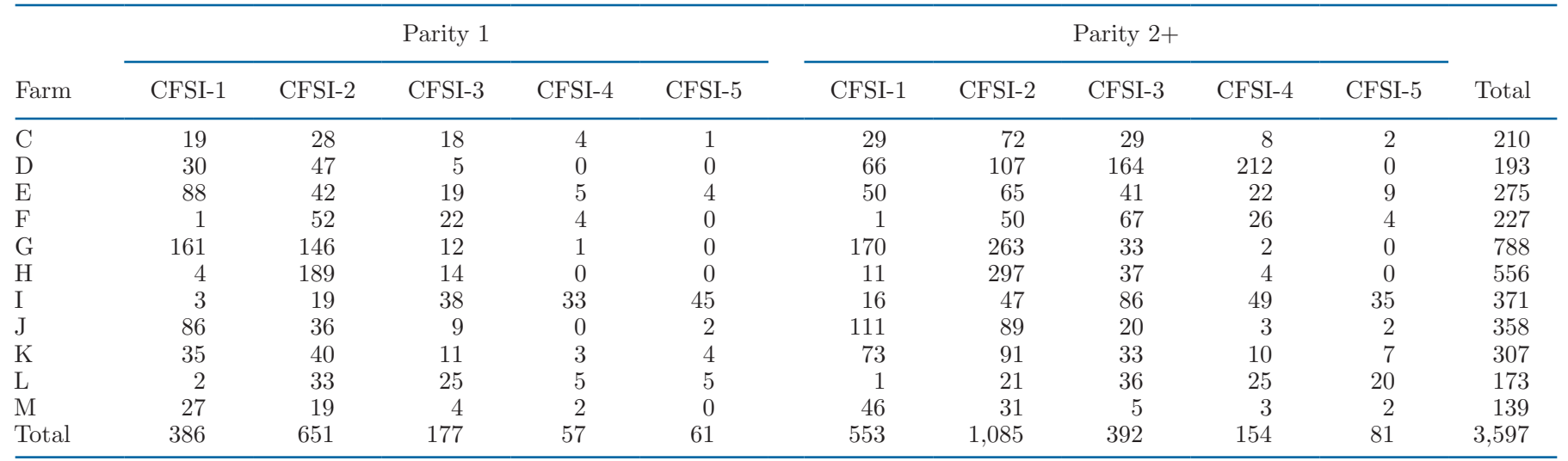

${ }^{1}$ CFSI-1 $<84 \mathrm{~d} ; 84 \mathrm{~d} \leq$ CFSI-2 $<140 \mathrm{~d} ; 140 \mathrm{~d} \leq$ CFSI-3 $<196 \mathrm{~d} ; 196 \mathrm{~d} \leq$ CFSI- $4<252 \mathrm{~d}$, CFSI-5 $\geq 252 \mathrm{~d}$.

Table A4. Mean calving to first service interval $\left(\mathrm{CFSI}^{1}\right)$ per farm, CFSI class, and parity class

\begin{tabular}{|c|c|c|c|c|c|c|c|c|c|c|}
\hline \multirow[b]{2}{*}{ Farm } & \multicolumn{5}{|c|}{ Parity 1} & \multicolumn{5}{|c|}{ Parity $2+$} \\
\hline & CFSI-1 & CFSI-2 & CFSI-3 & CFSI- 4 & CFSI-5 & CFSI-1 & CFSI-2 & CFSI-3 & CFSI-4 & CFSI-5 \\
\hline $\mathrm{E}$ & 64 & 113 & 157 & 212 & 302 & 62 & 112 & 160 & 218 & 301 \\
\hline $\mathrm{F}$ & 79 & 109 & 161 & 260 & NA & 83 & 117 & 162 & 216 & 279 \\
\hline $\mathrm{G}$ & 66 & 105 & 157 & 199 & NA & 66 & 107 & 155 & 214 & NA \\
\hline $\mathrm{J}$ & 67 & 104 & 153 & NA & 283 & 66 & 106 & 167 & 238 & 283 \\
\hline $\mathrm{K}$ & 70 & 103 & 153 & 236 & 356 & 69 & 109 & 160 & 224 & 290 \\
\hline $\mathrm{L}$ & 57 & 111 & 166 & 223 & 294 & 75 & 122 & 168 & 223 & 307 \\
\hline $\mathrm{M}$ & 61 & 98 & 166 & 215 & NA & 55 & 101 & 159 & 230 & 303 \\
\hline
\end{tabular}

${ }^{1}$ CFSI-1 $<84 \mathrm{~d} ; 84 \mathrm{~d} \leq$ CFSI-2 $<140 \mathrm{~d} ; 140 \mathrm{~d} \leq$ CFSI-3 $<196 \mathrm{~d} ; 196 \mathrm{~d} \leq$ CFSI- $4<252 \mathrm{~d}$, CFSI-5 $\geq 252 \mathrm{~d}$.

${ }^{2} \mathrm{NA}=$ not available; in this farm, parity class and calving interval class were no lactations. 
Table A5. Significant effects and interaction effects on fat- and protein-corrected milk of the modeled curves on time $=\mathrm{t}$ in kilograms per day

\begin{tabular}{|c|c|c|}
\hline Effect $^{1}$ & $F$-value & $P$-value \\
\hline CInt class & 22.36 & $<0.0001$ \\
\hline Parity class & $3,257.47$ & $<0.0001$ \\
\hline Farm & 61.48 & $<0.0001$ \\
\hline CInt class $\times$ farm & 3.76 & $<0.0001$ \\
\hline Parity class $\times$ farm & 8.52 & $<0.0001$ \\
\hline CInt class $\times$ parity class & 4.63 & 0.001 \\
\hline $\mathrm{b}$ & $4,302.88$ & $<0.0001$ \\
\hline $\mathrm{b} \times$ CInt class & 7.23 & $<0.0001$ \\
\hline $\mathrm{b} \times$ parity class & $1,826.08$ & $<0.0001$ \\
\hline $\mathrm{b} \times$ farm & 18.37 & $<0.0001$ \\
\hline $\mathrm{b} \times$ CInt class $\times$ farm & 2.23 & $<0.0001$ \\
\hline $\mathrm{b} \times$ parity class $\times$ farm & 9.17 & $<0.0001$ \\
\hline c & $1,007.8$ & $<0.0001$ \\
\hline $\mathrm{c} \times$ parity class & 52.46 & $<0.0001$ \\
\hline$c \times$ farm & 36.06 & $<0.0001$ \\
\hline$b_{\text {gest }}$ & $1,392.74$ & $<0.0001$ \\
\hline $\mathrm{b}_{\text {gest }} \times$ CInt class & 5.67 & 0.0001 \\
\hline $\mathrm{b}_{\text {gest }} \times$ parity class & 62.52 & $<0.0001$ \\
\hline$b_{\text {gest }} \times$ farm & 21.93 & $<0.0001$ \\
\hline $\mathrm{b}_{\text {gest }} \times$ CInt class $\times$ farm & 4.24 & $<0.0001$ \\
\hline $\mathrm{b}_{\text {gest }} \times$ parity class $\times$ farm & 10.7 & $<0.0001$ \\
\hline CFSI class & 27.94 & $<0.0001$ \\
\hline Parity class & $1,764.42$ & $<0.0001$ \\
\hline Farm & 64.87 & $<0.0001$ \\
\hline CFSI class $\times$ farm & 3.06 & $<0.0001$ \\
\hline Parity class $\times$ farm & 8.01 & $<0.0001$ \\
\hline CFSI class $\times$ parity class & 3.62 & 0.0059 \\
\hline $\mathrm{b}$ & $8,743.25$ & $<0.0001$ \\
\hline $\mathrm{b} \times$ parity class & $1,446.6$ & $<0.0001$ \\
\hline $\mathrm{b} \times$ farm & 34.46 & $<0.0001$ \\
\hline $\mathrm{b} \times$ parity class $\times$ farm & 8.96 & $<0.0001$ \\
\hline c & 347.95 & $<0.0001$ \\
\hline $\mathrm{c} \times$ CFSI class & 2.52 & 0.0393 \\
\hline $\mathrm{c} \times$ parity class & 13.33 & 0.0003 \\
\hline$c \times$ farm & 26.03 & $<0.0001$ \\
\hline $\mathrm{c} \times$ CFSI class $\times$ parity class & 3.43 & 0.0083 \\
\hline $\mathrm{b}_{\text {gest }}$ & 220.91 & $<0.0001$ \\
\hline $\mathrm{b}_{\text {gest }} \times$ CFSI class & 2.59 & 0.035 \\
\hline$b_{\text {gest }} \times$ parity class & 33.48 & $<0.0001$ \\
\hline$b_{\text {gest }} \times$ farm & 8 & $<0.0001$ \\
\hline $\mathrm{b}_{\text {gest }} \times$ CFSI class $\times$ farm & 5.38 & $<0.0001$ \\
\hline $\mathrm{b}_{\text {gest }} \times$ parity class $\times$ farm & 12.33 & $<0.0001$ \\
\hline
\end{tabular}

${ }^{1}$ CInt $=$ calving interval; CFSI $=$ calving to first service interval; $\mathrm{b}=$ inversely related to persistency; $\mathrm{c}=$ related to the beginning of lactation; $b_{\text {gest }}=$ inversely related to persistency after gestation effect. 